\title{
Allan Ramsay's Poetic Language of Anglo-Scottish Rapprochement
}

Allan Ramsay et le langage du rapprochement anglo-écossais

\section{Michael Murphy}

\section{(2) OpenEdition \\ 1 Journals}

\section{Electronic version}

URL: http://journals.openedition.org/etudesecossaises/919

DOI: 10.4000/etudesecossaises.919

ISSN: 1969-6337

\section{Publisher}

UGA Éditions/Université Grenoble Alpes

\section{Printed version}

Date of publication: 25 April 2015

Number of pages: 13-30

ISBN: 978-2-84310-296-7

ISSN: $1240-1439$

\section{Electronic reference}

Michael Murphy, "Allan Ramsay's Poetic Language of Anglo-Scottish Rapprochement", Études écossaises [Online], 17 | 2015, Online since 25 April 2016, connection on 15 March 2021. URL: http:// journals.openedition.org/etudesecossaises/919 ; DOI: https://doi.org/10.4000/etudesecossaises. 919 


\section{Allan Ramsay's Poetic Language of Anglo-Scottish Rapprochement}

Ramsay (1684?-1758), one of the last generation born in an independent Scottish state, was also part of the first generation of Hanoverian Britons; his career began just after the Treaty of Union of 1707 . There is a political tension in his writings: until the 1730s at least he hoped for the restoration of an independent, Stuart, Scottish kingdom, but he also worked for Anglo-Scottish reconciliation. The latter was neither a premeditated project on his part, nor direct support of the Hanoverian dynasty, their governments, or the terms of the Treaty of Union. It was a slow movement, measured notably through epistolary poems exchanged with Englishmen. These personal, literary contacts helped him to imagine a common future shared by two peoples, or more precisely their elites. Ramsay's writing demonstrates both open-mindedness and attachment to Scottish particularisms. This shows his attentiveness to the possibilities of a British future which would not deny two thousand years of Scottish history. Little studied, overshadowed by later illustrious Scottish poets, Ramsay is an unrecognised pioneer in the complex encounters between the two dominant British cultures.

A discreet Jacobite propagandist who increasingly profited from the Union of 1707 , Ramsay uses language as a way to reduce the contradiction and tension in his political positions. In particular, he uses language as a marker of Scottish identity. In a context of anglicisation of Scottish culture, Ramsay invents a poetic language which mixes elements of Scots with English, thus adopting a linguistic middle way. He thereby seeks a degree of consideration, even a form of equality, for Scots, faced with English, the language of power in the new state of Great Britain. Rather than prefer either Scots or English, which might be seen as a choice between extremes, one made by later contributors to the Scottish Enlightenment, he chose a diplomatic voice astride the Anglo-Scots linguistic border.

How does Ramsay's poetic language express both his attachment to Scotland's identity and his openness to a British identity shared with 
England? First, he both invents a "composite" Anglo-Scottish poetic language and uses traditional Scottish genres and metrical forms in order to express his political concerns, with national identity, but also with practical matters such as Edinburgh's economy and urban development. He seeks acceptance for a "mixed" form of Scots as a second British language alongside English. This mixed Scots facilitates comprehension by non-Scots readers while keeping a link with monoglot Scots, thereby creating a united Anglo-Scottish public. Ramsay also makes a plea in prose in favour of the dignity of Scots (its venerable age, its purity, its prestigious literary heritage...). Finally, his poetry itself provides proof of this dignity: Ramsay never satirises Scots as a language and avoids any simple dichotomy between "comic" Scots and "serious" English.

\section{A Composite Language}

While Ramsay uses Scots to give a Scottish colouring to his poetry and situates himself within a Scottish literary heritage through his use of particular verse forms, he intends to remain accessible to English readers as well as Scottish ones. Ramsay invented a poetic language composed of elements of both English and Scots: at least a third of his poems are wholly in English, ${ }^{1}$ but more than 12,000 lines of his published verse contain elements of Scots. ${ }^{2}$ The following description of this mixed poetic language is based on a typical sample: thirteen imitations of the Fables nouvelles (1719-1720) by Antoine Houdar de la Motte published by Ramsay in Fables and Tales (1722) and again in Poems (1728). ${ }^{3}$

The presence of Scots linguistic characteristics (grammar, syntax, vocabulary, and spelling) is evident. They represent ten to twenty percent of the words in each of the thirteen texts. ${ }^{4}$ Relatively modest, this

1. Ramsay's writing in English was influenced by Prior and Gay in particular. He admired Addison and Pope without using them as models. C. McGuirk, "Augustan Influences on Allan Ramsay", Studies in Scottish Literature, vol. 16, 1981, pp. 97-109.

2. Ramsay published more than 17,000 lines of verse. Poems (1721) includes 3,500 lines in Scots out of a total of under 6,000 lines, while Poems (1728) includes even more: 6,500 lines out of 8,500. Ramsay's other published poems include 2,300 lines in Scots out of a total of more than 3,000. Including his nonpublished manuscript verses, Ramsay produced some 16,000 lines of verse in Scots out of a total of 24,000 .

3. The imitations are: "To the Critick"; "Epistle to [...] Forbes"; "The Clock and Dial"; "The Lovely Lass"; "Jupiter's Lottery"; "The Miser and Minos"; "The Fox and the Rat"; "The Caterpillar and the Ant"; "The Twa Cats and the Cheese"; "The Camaeleon"; "The Twa Lizards"; "Mercury in Quest of Peace"; "The Phoenix and the Owl", Works (hereafter W followed by volume) 2, pp. 1, 24, 28, 35-9, 42-53, 124.

4. Scots linguistic traits as a percentage of the total words per text: "Mercury in Quest of Peace" (13\%), "The Owl and the Phoenix" (15\%), "The Twa Books" (18\%), "The Chamaeleon" (20\%). 
percentage must be contextualised: English and Scots share eighty nine percent of their vocabulary. ${ }^{5}$ Reading aloud with the accent of Scots speakers highlights further the features of Scots, which partly explains why Ramsay describes his poems as written in "Scots" or even "Braid Scots". ${ }^{6}$ Ramsay's mixed language is never far from English, thereby making it a marker of Scottish cultural difference yet accessible to English readers. Scots grammatical and syntaxic features are rarely employed. Ramsay also makes accessible to English speakers those linguistic features of Scots which he uses most. The spelling system, with a difference of one to three letters compared to Standard English — "amaist [almost]", "braid [broad]" - is thus explained to non-Scots readers in over 120 examples. ${ }^{7}$ Corbett has pointed out how Ramsay's spelling signals the hybrid nature of Scots, for example through his invention of the so-called apologetic apostrophe. Thus, "ha'e" indicates the proximity between the English "have" and the Scots word pronounced differently, since glottalised. ${ }^{8}$ Ramsay uses over 1,500 words specific to Scots (Fergusson uses 1,600 and Burns 2,500). ${ }^{9}$ The essential elements of these are explained in English in a glossary in each volume of Poems (1721 and 1728). Besides, the meaning of Scots vocabulary is often given by its context. Exceptionally, a poem in Scots is accompanied by its English translation. ${ }^{10}$ Over half of the rhyme word pairs used in the thirteen imitations are pairs of English words. Mixed pairs in which an English word is rhymed with a Scots one ("print"/"tint" [to break], "help"/"skelp" [to run fast]), represent a third of cases at most. Paired Scots words ("tent"/"bent", "sae"/"wae") rarely exceed ten percent of occurrences in a given text. In principle, the most difficult case for a non-Scots reader is the pronunciation of a Scots word. How can one know that head is pronounced /hi:d/, and when?

The thirteen texts contain at least one Scots linguistic trait in more than half of all the lines of verse, while certain texts contain at least one trait in $80 \%$ of verses. One or two Scots traits per line is the most frequent case. The following verse with five Scots traits is exceptional: "If ane may true his ain twa Een" ["If one may believe his own two Eyes"] ("The Chamaeleon", W2, p. 47, vs. 12).

5. Within the following language couples the coincidence of vocabulary exceeds $90 \%$ : Czech and Slovak, German and Dutch, Norwegian and Swedish. J. D. McClure, Why Scots Matters, p. 23. 18\% of Robert Burns's vocabulary is Scots. W. Grant, "Introduction", Chambers Scots Dictionary.

6. "Advertisement to Fables and Tales" (1722), manuscript dedication (n.d.) in a copy of Fables and Tales, quoted in W4, pp. 234, 259.

7. "[S] ome general Rules shewing wherein many Southern [English] and Northern [Scots] Words are originally the same, having only a Letter changed for another, or sometimes one taken away or added." (W1, p. 247)

8. J. Corbett, "The spelling practices of Allan Ramsay and Robert Burns", in W. Anderson (ed.), Language in Scotland, pp. 65-90. Scots 18th-Century orthography was not a fixed one.

9. Fergusson estimation, A. M. Kinghorn and A. Law, "Introduction", Poems by Allan Ramsay and Robert Fergusson, p. xxx; Ramsay and Burns estimations, W6, p. 200.

10. "Richy and Sandy, A Pastoral on the Death of Joseph Addison" is accompanied by a version in English by Josiah Burchett (1666?-1746), Secretary to the Navy. 
Ramsay gives an indication in most cases of pairs of mixed language rhyme words: "indeed" is followed by "head", which is here pronounced /hi:d/, and "Beast" preceeds "Breast", pronounced /bri:st/.

Besides creating a poetic Anglo-Scots language distinct from English, Ramsay may also employ both languages, English and Scots, within the same text. Thus, the fifty or so glossed words in the Familiar Epistles (a series of epistolary exchanges in which the "Scots" element is quite strong) are written in the South of England standard. ${ }^{11}$ The glosses, explaining numerous Scottish references, linguistic and other, appear to be for a non-Scottish public. Ramsay's intention is again to help nonScots readers. While English dominates in most of our sample, Ramsay's mixed language enables him to choose English, Scots, or a mixture of both. Thus, in "Mercury in Quest of Peace", pairs of English rhyme words represent eighty percent of cases, but there are other choices: either pairs composed of an English word and a Scots one, differentiated by spelling ("plane"/"alane"), pronunciation ("head"[/hi:d/]/"speed"/"indeed", where the "Scots" pronunciation is in first position, which is rare), vocabulary ("drinkers"/"jinkers"), or Scots pairs: "gaes"/"Faes". In summary, the Scots characteristics of Ramsay's composite language are numerous but represent a minority of cases, thereby giving a Scots colouring to his writings. Glossaries, the explanations of the spelling, and help within the texts, make the poems accessible to non-Scots readers.

The Scots colouring of Ramsay's poems is reinforced by the use of Scottish genres and metrical forms (later employed by such as Robert Fergusson and Robert Burns). In his poems in "Scots", Ramsay especially uses four genres: the burlesque or "peasant fight" type (known in Scotland as the Christis Kirk genre, named after the generic medieval text); the humorous elegy genre about a bagpipe player created around 1640 by Robert Sempill of Beltrees, and used by Ramsay for characters of low social rank ("Elegy on Maggy Johnston" ...); the comic testament or Last Words genre, of medieval origin, ressuscitated in 1706 with "The Last Dying Words of Bonny Heck [...]" by William Hamilton of Gilbertfield, and employed by Ramsay, notably in "Lucky Spence's Last Advice" and in "The Last Speech of a Wretched Miser"; finally, Ramsay created a Scottish version of the verse epistle, beginning with those exchanged with Hamilton of Gilbertfield in 1719. He wrote sixteen epistles, including the following imitation of Horace (Odes, Book 1, Ode 11):

11. Ramsay explains a Scots phrase used by Hamilton of Gilbertfield: "'Tis usual [...] after a full Laugh, to [...] bestow a kindly Curse on the Author of the Jest. But the Folks of more tender Consciences have turned their Expletives to friendly Wishes, such as [... 'Wae gae by him!' [...]." ("Epistle III", W1, p. 134n) 
My Trusty TROJAN [...]

NE'ER fash about your neist Year's State,

Nor with superior Powers debate,

Nor Cantrapes cast to ken your Fate;

There's Ills anew

To cram our Days, which soon grow late;

Let's live just now.

WHEN Northern Blasts the Ocean snurl, And gars the Heights and Hows look gurl,

Then left about the Bumper whirl, And toom the Horn,

Grip fast the Hours which hasty hurl, The Morn's the Morn [...]

Yours ALLAN RAMSAY. ${ }^{12}$

Ramsay also employs four Scottish metrical forms. The verse form called Christis Kirk consists of eight lines which alternate iambic tetrameter, rhymed abababab, followed by a dimeter:

BUT there had been mair Blood and Skaith,

Sair Harship and great Spulie,

And mony a ane had gotten his Death

By this unsonsie Tooly:

But that the bauld Good-wife of Braith

Arm'd wi' a great Kail Gully,

Came bellyflaught, and loot an Aith,

She'd gar them a' be hooly

Fou fast that Day. $(W 1, \text { p. } 66 \text {, Chant II, vs. } 1-9)^{13}$

The Cherrie and the Slae stanza form (after Alexander Montgomery, c. 15501598 ) is composed of fourteen quite complex lines, rhymed aabccbdedefghg. The following extract is from "The Poet's Wish: An Ode" imitates Horace's Odes, Book I, Ode 31:

FRAE great Apollo, Poet say,

What is thy Wish, what wadst thou hae,

When thou bows at his Shrine?

Not Karss o' Gowrie's fertile Field,

Nor a' the Flocks the Grampians yield,

That are baith sleek and fine:

Not costly Things brought frae afar,

12. "Answer III" [to Hamilton of Gilbertfield], W1, pp. 131-2, vs. 31-42, 96.

13. "Edinburgh's Salutation to the Most Honourable, My Lord Marquess of Carnarvon" (1720?) also uses this metrical form, while "The Marrow Ballad" (1738) resorts to a variant. 
As Ivory, Pearl and Gems;

Nor those fair Straths that water'd are

With Tay and Tweed's smooth Streams,

Which gentily and daintily

Eat down the flowry Braes,

As greatly and quietly

They wimple to the Seas. (1721; $W 1$, p. 243, vs. $1-14$ )

This stanza form is also used in "The Vision". Ramsay's use of the stanza form he baptized "Standart Habbie" and of the tetrameter couplet is more typical and important for the later poetic tradition in Scotland. Now called the "[Robert] Burns stanza", the former counts six lines which alternate tetrameters and dimeters rhyming aaabab. "The Last Speech of a Wretched Miser" is the longest example (29 stanzas):

O Gear! I held ye lang thegither

For ye I starv'd my good auld Mither,

And to Virginie sald my Brither,

And crush'd my Wife:

But now I'm gewn I kenna whither;

To leave my Life. (1724; W2, p. 67, vs. 139-44) ${ }^{14}$

Ramsay uses the tetrameter couplet, a medieval narrative verse form, in the following: his four fables of 1724-1728 ("The Monk and the Miller", "The Miller and his Man", "The Clever Offcome", "The Lure"), "The Three Bonnets", all but one of the Fables and Tales, in verse epistles. It is also employed in certain Horatian imitations, such as "An Ode to $\mathrm{Mr}$ F[orbes]", which includes an imitation of Ode 4, Book 1:

O kanny F ! tutor Time,

And live as lang's ye'r in your Prime;

That ill bred Death has nae Regard

To King or Cottar, or a Laird,

As soon a Castle he'll attack,

As Waus of Divots roof'd wi' Thack. (W1, p. 222, vs. 25-30)

Ramsay's poetry seeks to remain accessible to English readers. His "bilingualism" reflects in part that of the Scottish elites of the period, rooted in the Lowlands through their use of Scots, yet open to England. Sir William Worthy and his son (The Gentle Shepherd/TGS) are bilingual. Sir William uses English with touches of "Scots" - only three occurrences in the forty four lines of his first soliloquy, for example (TGS 3.1,

14. This metrical form is often used by Ramsay, in his six humorous elegies, his comic testaments, satires, some epistles and a pastoral elegy. 
vs. 9-52): "peeble [pebble]", "beild [shelter]", "hame [home]". His disguise as a fortune teller is however completed by his linguistic transformation, witnessed by his reply to a farmer enquiring if he has walked far: "I pledge ye, Nibour: — E'en but little Way: / — With Eild, a wee Piece Gate seems lang; / Twa Miles or three's the maist that I dow gang" (TGS 3.2, vs. 69-71). Sir William Worthy appears credible in his assumed role. His knowledge of peasants, his mastery of their language, enables him to behave like one of them. He knows and masters two worlds and two modes of expression.

His son Patie the shepherd usually speaks to his sweetheart in Scots: "Her Cockernony snooded up fou sleek, / Her Haffet-Locks hang waving on her Cheek; / Her Cheek sae ruddy, and her Een sae clear" (TGS 1.1, vs. 115-7). Once recognized as Patrick, the lost son of the laird, he expresses himself in the English language of his father: "Sir, here's my trusty Friend, that always shar'd / My Bosom-secrets, ere I was a Laird; / Glaud's Daughter Fanet [...] / Rais'd, and maintains in him a Lover's Flame" (TGS 5.3, vs. 199-202). The Scots elements of the spoken language of this new heir are minor: "lang" for "long", for example. Strikingly, the new heir, just welcomed into a superior socal category, is able to move easily from one mode of expression to the other. Thus, he addresses his father in English to present his sweetheart, formally called Janet for the first time in the play, then speaks to her in Scots: "Glaud's daughter Janet (Jenny, thinkna Shame)". The rapidity of this linguistic metamorphosis partly translates the social transformation of Patie in a symbolic fashion. It can also be interpreted more realistically: Patrick simply begins to speak in public a language that he already knows and reads aloud in private. He has learned to read and speak Standard English, the "King's English"_ "I crack [talk] with Kings"_-, as confirmed by the farmer who raised him:

About ane Shakspear, and a famous Ben,

He aften speaks, and ca's them best of Men. [...]

I sometimes thought he made o'er great a Frase,

About fine Poems, Histories and Plays.

When I reprov'd him [...]

With this [book], quoth he, on Braes I crack with Kings.

(TGS 3.4, vs. 73-4, 78-81)

Ramsay's linguistic choices thus signal his wish to favour the accessibility of his poetry to a public beyond Scotland, while keeping a degree of dialectal rootedness. This attitude can be seen as reflecting the bilingualism of the Scottish elites, open towards England, but keeping links with monoglot "Scots" social categories. Ramsay's poetic language, English 
or mixed, his use of Scottish metrical forms, are never unsurmountable barriers to non Scots speakers/readers, never a closed linguistic border between Scotland and England. His bilingualism suggests a certain willingness to follow the opening of the Scottish land-owing elite towards the neighbouring country. Beyond the commercial interest of the Englishspeaking market, Ramsay's linguistic priorities represent a symbolic rapprochement between England and Scotland.

\section{A Dignified Language}

While Ramsay continued to write Jacobite and anti-unionist poems until the 1730s, the language he employs hints at his evolution over time in favour of British understanding and unity. However, he does not appear to follow a path towards assimilation and the loss of the differences between Scotland and England. His poetic language constitutes one of the expressions of his wish to conserve certain Scottish differences, and to have them respected by the English. He preserves aspects of the literary heritage of the Scottish Renaissance, seeks to establish the value of Scots ("Scoto-Saxon") as a venerable and prestigious cousin of English ("Anglo-Saxon"), thereby suggesting that British political union might also consecrate the coexistence of two British languages and a form of British bilingualism.

Ramsay works in a specific linguistic context. Scots originates at the time of the Scottish conquest in 1018 of the northern territories of the Kingdom of Northumbria. This was home to the Northumbrian dialect of Late Anglian, thereafter divided into a northern (Scottish) and a southern variant. ${ }^{15}$ Near the end of the 14th century, the East Midlands dialect (descended from the other main dialect of the Angles-Mercian) came to dominate all of England except the North-East: Northumbrian then became a patois, losing its role as a linguistic link between the Scottish Lowlands and Southern England. ${ }^{16}$ During the Scottish Renaissance

15. Five languages were spoken in 11th-Century Scotland: Q-Celtic Irish Gaelic in the Western Highlands; P-Celtic British (Cumbrien) and Pictish in the West, Central and North-East Lowlands; Scandinavian dialects in the Hebrides (ceded to Scotland in 1266), the Orkneys and Shetlands (ceded to Scotland in 1472); Inglis (Middle Scots) in the South-East. Kay, Scots: The Mither Tongue, p. 28. Following the unification of Scotland in 1018 by the acquisition of lands beyond the Tweed from the Anglian kingdom Northumbria, Malcolm III (1058-1093), transfered his court to the new, non-Gaelic speaking region, and married a West Saxon, after which Irish, the language of the Scots (originally from Ireland), declined in Scotland. O Murchú, The Irish Language, p. 20.

16. McClure, "Scottis, Inglis", p. 6; W. Grant, "Introduction", p. vIII. The written language in Scotland and England did not diverge much before the end of the 14th century. Brus by John Barbour (c. 1375) is the first literary text in inglis. As for England, the development of this vernacular language had been slowed down by the use of Latin and French. Devitt, Standardizing, p. 9. 
(circa 1460-1560) the literature of the Stuart court was brilliant and a de facto standard form of Middle Scots developed in Edinburgh and its hinterland (Devitt, Standardizing, pp. 9-10). The dominant dialects in England and Scotland remained mutually comprehensible, though in their written, rather than their oral, forms (McClure, "Scottis, Inglis", p. 61), but were considered as different since they were spoken within different political states (abstand languages). ${ }^{17}$ The Inglis dialect dominant in the Lowlands began to be called Scottis from 1513 onwards. ${ }^{18}$ The arrested evolution of the official language of the Scottish state was due to the departure of the Stuart court for London (1603). However, the rapid convergence of the dominant dialect of Scotland with that of England was but a step in the linguistic anglicisation of Scotland which began about the time of the Protestant Reformation. ${ }^{19}$ The Middle Scots period thus lasted from about 1450 to around 1650. Seventeenth-century prose in Scotland was mediocre. ${ }^{20}$ The poetry then, produced by individuals often known for a single poem, was condescending to Scots, increasingly reduced to an agglomerate of rural and peasant dialects (Daiches, "Scottish Literature to $1700 "$, p. 531). ${ }^{21}$ The spoken language became anglicised more slowly: the Scottish aristocracy moved closer to the standard oral English of the London court during the 17th century, followed by the middling ranks, especially after $1750 .^{22}$

17. For the Spanish Ambassador, the language spoken at the court of James IV Stuart (1488-1513) was as different from London English as Catalan from Castillian. Norwegian, Danish and Swedish are modern abstand languages, along with Portuguese and Galicien. McClure, Why Scots Matters, pp. $27-8$.

18. Gavin Douglas (Eneados) uses the term first. Moessner, "Besyde Latyn our langage is imperfite", p. 7. However, one should not exagerate the importance of these isolated references: in the mid-16th century, the language(s) of England and Scotland were considered as one by a Scot, though himself hostile to the English: "There is nocht twa nations [...] mair contrar and different [...] nor is Inglis men and Scottis men, whoubeit [...] nychbours, and of ane language." Anon., The Complaynt of Scotlande (Paris, 1549), ch. XIII, in Civardi, L'Écosse, p. 14.

19. Religious works were the first to adopt the English standard. This process started about 1520 was completed before 1600. The official correspondance and archives of private individuals began to be anglicised from 1580 onwards, private correspondance from 1600 onwards, and public archives from 1620 onwards. The period 1580-1640 shows fairly rapid linguistic anglicisation, especially in 1600-1619. Devitt, Standardizing, pp. 40, 46, 58-60.

20. Reid, The Party-Coloured Mind. Written in English, the poetry of Scottish courtiers at the English court of James I is already a merely conventional exercise. Daiches, "Scottish Literature to 1700", pp. 529-30. The poetry of William Drummond of Hawthornden (1585-1649), who did not leave Scotland, is also written in English.

21. However, the regional dialect of the Lothians (Mid-Lowland) remained dominant, the other important dialect being North-Lowland, dominant in the Aberdeen area. Grant, "Introduction", pp. XV-XVII.

22. Cf. The Scotticisms listed in Hume's Political Discourses (1752), those criticised by Smollett (Critical Review, from 1756 onwards), the elocution courses of the Irishman Thomas Sheridan (Edinburgh, 1761). 
Ramsay partly succeeded in reestablishing the dignity of Scots in this context of linguistic anglicisation and dialectisation, which appeared to condemn it to become a patois. He reestablished "Scots" - i.e. his mixed poetic language - as an appropriate language in a variety of poetic genres, including some "serious" ones, without seeking to measure up to the English masters of the most prestigious poetic genres. Ramsay counted in part on the English interest in the history of their own main dialect, a cousin of Scots. The publication of The Ever Green, an anthology of poems belonging to a "northern" and "Scottish" tradition (Preface, The Ever Green, W4, p. 236), can be situated in the context of studies in England from the 17th century onwards of Danish and Icelandic poetry, as well as Anglo-Saxon and Chaucerian English. In the Preface of this anthology Ramsay associates Scots with the "force of thought and simplicity of style" of Middle Scots, and quotes a comparison made by a London critic between the language of Ramsay and that of the English poets of the past, such as Chaucer, Spenser and Shakespeare: "A small acquaintance with that Language [Scots], and our old English Poets, will convince any Man, that we [...] may be treated at home [i.e. in Britain] with more substantial, as well as a more elegant Entertainment [than abroad]" (Dr Sewel, quoted in W1, p. XIX). To his plea "in favour of our language", Ramsay adds that Scots speakers profit from a richer pronunciation, and a wider range of vocabulary in Scots than in English, while mastering the latter. ${ }^{23}$

Scots can thus aspire to the same status as English, as one of the two British languages, i.e. Scoto-Saxon and Anglo-Saxon. Ramsay further describes Scots as a component of British, coining a new appellation for the language of Great Britain, included in a list of prestigious languages: "British [i.e....] the Scots and English Tongue [...], Hebrew, Greek and Latin" (Preface, W1, p. XVIII). Following Ramsay, the defence of the dignity of Scots as a living memory of one of the dialects from which modern English was born becomes a leitmotif of Scottish literature. ${ }^{24}$ Ramsay does not always support Scots as strongly, since he recognises that it

23. "[T] he Prononciation [of Scots] is [...] much fuller than the English, of which we are Masters, by being taught it $[\ldots]$, and daily reading it; which [...] added to all our own native Words $[\ldots]$ makes our Tongue by far the completest [...] I can say, an empty house, a toom Barrel, a boss Head, and a hollow Heart." (W1, p. XIx)

24. Lismahago expresses himself thus on the subject in Humphry Clinker (1771): "He said, what we $[\ldots]$ called the Scottish dialect was $[\ldots]$ genuine old English [...]; Chaucer, Spenser, and even Shakespeare, were [...] unintelligible to the natives of South Britain, wheareas the Scots, who retain the antient language, understand them without [...] a glossary" (p. 235). W. Scott has his amateur of antiquarian studies say the same: "Oldbuck [...] repeat[ed ...] the verses of old Chaucer [...] giving each gutteral the true Anglo-Saxon enunciation, $[\ldots]$ now forgotten in the southern part of this realm [i.e. England]." (The Antiquary, p. 23) 
may appear rustic, outdated, socially inferior, compared with English. ${ }^{25}$ However, he insists that Scots can be elegant and fitting for a polyglot gentleman. Again, this suggests that Ramsay considers bilingualism as a minimal norm for members of the Scottish elites; he associates monolingualism with socially inferior categories:

[...] nothing [... is] more silly than one's expressing his Ignorance of his native Language [...] shew [Fops] the most elegant Thoughts in a Scots Dress, they as disdainfully as stupidly condemn it as barbarous [...] But [...] most [... of our Gentlemen [...] Masters of the most useful and politest Languages, can take Pleasure (for a change) to speak and read their own. (Preface, $W 1$, p. XIx)

It should be noted that Scots Gaelic is not mentioned by Ramsay, though he occasionally uses anglicised versions of Gaelic words. A case might have been made in favour of the venerability, the purity, the literary quality of Scottish Gaelic (close to Irish Gaelic), still largely spoken at the time in the Highlands, which remained home to half of the population of Scotland. However, Ramsay does not attempt to defend this former language of the independent Scottish state, which had lost its prestige since the Stuart Court left Stirling near the Highland boundary in favour of Scots-speaking Edinburgh; he ignores Gaelic. The venerable age of Scots, its purity, its prestigious literary heritage, favourable comparisons with English, as well as with other prestigious living and classical languages; that its use is seen as appropriate for a gentleman; that it is associated also with farmers, "the Props of the Nation's Profit" (W5, p. 62); all this pleads in theory in a fairly efficient manner in favour of the dignity of Scots. The poetry of Ramsay provides elements of proof.

\section{A Dignified Poetry}

Ramsay often uses his composite Scots in contexts of rural peasantry and urban criminality, but this is to recall a medieval literary tradition and not to denigrate the language. This is proven by Ramsay's use of Scots in politically militant poems associated with the social elite, as well as in other prestigious genres, such as satire. At first view, Ramsay's poetry associates his mixed language with the peasantry, and even with urban petty criminals, which hardly argues for the dignity of Scots. However, criticising peasants is a traditional theme of medieval origin and with

25. For example, in the Preface in Scots of his collection of proverbs: "Publishers [... do] not understand our Landwart Language [...] Some amang the [Scottish] Gentle [...] may tartle at the Braidness, or, (as they name it) coarse Expressions." (W5, p. 61) 
aristocratic overtones, neither specific to Scotland, nor linked to the belittling of Scots. ${ }^{26}$ Thus, in "Christ's Kirk on the Green", typical of a genre which satirises peasant behaviour, their language itself is never a target. This poem is in effect a successful imitation of the language of the Renaissance poet-king James I. Other poems belonging to this genre, such as "The Monk and the Miller's Wife" and "The Miller and his Man", are written in tribute to the Scottish poet Dunbar and the English poet Chaucer. ${ }^{27}$ Ramsay also reproduces the spoken Scots of a town prostitute or of a miser not to satirise the language, but as a "realistic" reproduction of the voices of the latter characters which, by an effect of irony, becomes a familiar and efficient tool to criticise a behaviour seen as unworthy and also dangerous for the community.

Ramsay links Scots with a variety of poetic genres. In the index of Poems (1721) the classification indicates that eight of the nine "comic" poems are in Scots, while nine of the thirteen "serious" poems are in English. This might suggest a simple dichotomy between "comic" Scots and "serious" English. However, besides the fact that in Ramsay's poetry Scots can be "serious" (four poems in Scots may be included in this category, i.e. almost one third), its presence in five other categories indicates the variety of its use. Thus, the three pastoral poems are in Scots as well as three quarters of the epistles (14: 17), two thirds of the satires (4: 6), more than half of the lyrical poems (17:26) and the epigrams (4:7). This suggests a continuum: the pastorals, the epistles, the satires, the comic poems, are more often than not in Scots, though they can be in English; the lyrical poems and the epigrams are as often in Scots as in English; the most serious verses are in English but are occasionally in Scots. ${ }^{28}$

The following categories of poems will exemplify Ramsay's use of Scots: the pastoral elegies, the militant poems, his poems on the economy, his texts opposing religious extremism and in favour of moderation and toleration. Concerning the elegies, one cannot limit their language to a simple peasant expression, since the two examples of the genre concern Steele ("Richy"), Pope ("Sandy") and the Duke of Oxford ("Robert") "dressed" as shepherds and speaking Scots. "Robert, Richy and Sandy" starts with the evocation of Robert in mourning:

26. Jones, "Christis Kirk", pp. 101-25; Kinsley, "The Rustic Inmates of the Hamlet", pp. 13-25.

27. In The Gentle Shepherd, besides the bilingualism of Sir William and of Patrick, Scots is above all associated with wisdom, loyalty, reason, and work. The clowning and superstition expressed by Bauldy are exceptions to this. However, it is not the language of Bauldy which is criticised but the beliefs and behaviour of the lower social category represented by this agricultural servant.

28. Cf. "Richy and Sandy, A Pastoral on the Death of Joseph Addison, Esq", W1, pp. 106-11. Ramsay dedicated an elagiac fable in Scots to the eldest son of Clerk of Penicuik. "The Phoenix and the Owl", W2, pp. 124-5. 
By break of Day he seeks the dowy Glen,

That he may Scowth to a' his Mourning len:

Nane but the clinty Craigs and scrogy Briers

Were Witnesses of a' his Granes and Tears. (W2, p. 18, vs. 9-12).

At the announcement of the death of the English poet Matthew Prior, Richy and Sandy remember bad omens in their dreams ${ }^{29}$ and the strange behaviour of their livestock:

Richy: My Heart misga'e me, when I came this Way,

His Dog its lane sat yowling on a Brae;

I cry'd, Isk-isk, — poor Ringwood, — sairy Man;

He wag'd his Tail, cour'd near, and lick'd may Hand:

I clap'd his Head, which eas'd a wee his Pain;

But soon's I gade away, he youl'd again.

Poor kindly Beast... (W2, p. 19, vs. 23-9)

While recognising the strangeness of these Englishmen speaking Scots, one should note the effort to produce a less formal elegy, a vehicle for natural, simple feeling. The pragmatic tribute paid to the deceased, in the style of a proverb, acquires a verisimilitude of sincerity by avoiding expressions of abstract and sophisticated pain. Ramsay "unmasks" behaviour by presenting mourning without cosmetic, pompous discourse. The peasant mask liberates and reveals the gentleman more than it hides him. This recalls one of the principal themes of The Gentle Shepherd: to liberate Scottish native feelings and behaviour from their mannerisms imported from France and the London court. Thus, Ramsay does not employ Scots only as a peasant language. Nor does he consider English as the only language of the elite. ${ }^{30}$

During the 19th century, Scots was quite often associated by Scottish novelists with positive moral traits, while English was associated with negative ones. ${ }^{31}$ In his politically militant poems, as elsewhere, Ramsay does not create this systematic opposition. In "The Three Bonnets", the Scots spoken by Bristle expresses honesty and virility, Joukum's Scots links it

29. Cf.: "LAST Ouk I dream'd my Tupe that bears the Bell, / And paths the Snaw, out o'er a high Craig fell, / And brak his Leg. - I started frae my Bed, / Awak'd, and leugh. - Ah! now my Dream it's red." (W2, p. 19, vs. 31-4)

30. It is also a Scottish contribution to the debate on the possibility of a modern pastoral, in which Addison, Pope and Prior ("The Nut-Brown Maid") participated.

31. Letley finds examples in the novels of John Galt ("the anglicised speech or writing is attached to an affected or otherwise unappealing character"), George MacDonald ("MacDonald counterpoints negative associations which attach to Standard English and positive ones with Scots"), and R. L. Stevenson ("In The Weir of Hermiston], Archie's formal English is set against Christina's Scots [...] the language contrast stresses the idea that Archie is in conflict with the culture to which he is trying to adapt himself"). Letley, From Galt to Douglas Brown, pp. 67, 93-4, 211. 
with threat and moral bankruptcy, that of Bawsy is associated with laziness and baseness. Rosie (England personified), spendthrift, manipulative and seductive, also expresses herself in Scots. Neither does Ramsay attach Scots exclusively to Scottish patriotism. Most of his militant poems are in English, for he admires the polyglot Scottish gentleman capable of expressing himself in English as well as in other classical or modern languages, incuding his native tongue: "his native Language". This contradicts any idea of a simple dichotomy between English and Scots. The militant poems associate Scots with the aristocrats, the lairds, the burgesses, as one of their possible languages of expression. The peasant voice is not represented in these politically militant poems, either in Scots or in English.

Certain poems supporting the economic development of Edinburgh or of Scotland are in Scots. In Poems (1721), where all the texts on this theme are classified as "serious", "Prospect on Plenty: A Poem on the North-Sea" is in fairly marked Scots - one linguistic trait every five words on average - , as is "Edinburgh's Salutation to the Marquess of Carnarvon", while "Edinburgh's Address to the Country" contains a hint of Scots. "Tartana, or the Plaid" is in English, but its second edition is in Scots. The preface to Proverbs, where Ramsay addresses the farmers of Scotland in Scots, does not mention the cottiers or other inferior ranks of Scottish society. Here again Scots is associated with the Scottish economy, a serious and patriotic theme. Finally, Scots is the usual language of Ramsay's satires, a moral genre, as well as of the poems against religious fanaticism and supporting moderation and toleration. In "The Chamaeleon", part of the series of fables in Scots concerning truth, justice, wisdom, peace, hypocrisy ..., Ramsay rejects attempts to impose one's opinions by force and underlines the fragility of human witness unassisted by reason:

\section{[...] learn to own your Nibours Sight}

As good as yours. - Your Judgment speak,

But never be sae daftly weak

T’imagine ithers will by Force

Submit their Sentiments to yours. ( $W 2$, p. 48, vs. 44-8)

Ramsay restores dignity to Scots through his prose defence of the language, but more so in his poems. He could not produce important work in the most prestigious genres, and therefore could not reimpose Scots as a complete poetic language. However, the genres evoked here do not suggest that he wished to defend a burlesque language associated with ridiculous and socially inferior characters. The latter simplification was introduced by literary critics. Towards the end of the 18th century, editors of collections of medieval Scottish poetry and traditional songs 
began to criticise the quality of Scots used by Ramsay, both as editor and as poet, distinguishing between his Scots, the language of an ignorant and vulgar clown amusing the lower ranks of society, and the language of the Scottish royal court:

[Ramsay's] convivial buffonery [...] is [...] that of an alehouse. [...] the effect of The Gentle Shepherd [TGS] is ludicrous from the contrast between meanness of phrase, and dignity or seriousness of sentiment. This [...] proceeds from [...] Ramsay's own character as a buffoon, so evident from all his poems [...]; and from Allan's total ignorance of the Scotish [sic] tongue, save that spoken by the mob $[\ldots]$ he was forced to use the very phraseology of the merest vulgar, rendered yet more ridiculous by his own turn to low humour; being himself indeed one of the mob, both in education and in mind. [TGS is] the very dirt of amusement only for the merest mob. ${ }^{32}$

The erudition cannot hide the refusal to take seriously an upstart poetbarber. ${ }^{33}$ Such arguments founded what became in the 20th century a certain criticism of Ramsay who, far from advancing the linguistic cause of Scots, is said to have created confusion about this element of national identity. ${ }^{34}$ The echo of 19 th-century European nationalisms can be heard here. ${ }^{35}$ However, Ramsay's country is still marked by an important Gaelicspeaking minority, and he does not found Scottish identity exclusively on the use of Scots. At the time, Lowland Scots do not seem to have shown linguistic loyalty to "their" language (Devitt, Standardizing, p. 15). Besides, only the vulgus pecum were limited to Scots; Ramsay writes for the English speakers as well as the bilingual and polyglot Scots. The linguistic argument against Ramsay, with its roots in Romanticism and Nationalism, also ignores that anglicisation was almost complete by 1650 for the written language. ${ }^{36}$ This argument would have Ramsay made responsible

32. Pinkerton, Ancient Scotish [sic] Poems (1786), pp. CXxxII-III. The criticism by Pinkerton (17581826) became a reference for later critics since it appeared in an erudite edition of ancient poems.

33. Fullerton seems to be the only critic to supect these non-dits. "An Appendix", Works, vol. 3, p. 292.

34. "Ramsay's work symbolizes (and actually contributed to) the cultural confusion of eighteenth century Scotland [...] Ramsay is no less culturally confused as an editor than he is as a poet." (A.H. Inglis, "Ramsay, Allan", p. 436) This notion of confusion is often linked to that of "duality" (or cultural schizophrenia): "The dualism in Ramsay's life and character was deep-seated and corresponded to a dualism in the Scottish culture of his day." (Daiches, "Scottish Literature from Allan Ramsay to Walter Scott", A Critical History, vol. 3, p. 813)

35. "[E]very Irish-feeling Irishman, who hates the reproach of West-Britonism, should set himself to encourage the efforts $[\ldots]$ to keep alive our once great national tongue. The losing of it is $[\ldots]$ the sorest stroke that the rapid Anglicisation of Ireland has inflicted upon us." (Douglas Hyde [future first President of Ireland], "The Necessity for De-Anglicising Ireland", 1892, quoted in Curtis, Cause of Ireland, pp. 163-4)

36. Cf.: "[...] combined, the [... linguistic anglicization following 10th century conquest of the Lothians, then attacks on the Gaelic-speaking Highlands ...] eliminated, 'before' the age of nation- 
for having failed to stop the dialecticisation of Scots, which might otherwise have served as a linguistic basis for nationalism as elsewhere in Europe during the 19th century.

Ramsay lacked the genius of Burns, the revolutionary force of Hugh MacDiarmid (1892-1978) who experimented with a dialectal synthesis and recommended a return to the texts of the Scottish Renaissance, bypassing the 18th century (and Ramsay). Yet Ramsay strongly contributed to the existence today of a debate on the future of Scots. ${ }^{37}$ For Fergusson and Burns, Ramsay represented the only model of poetic success in Scots. The only link possible between their language and Middle Scots was that made by Ramsay, as poet and editor. Without him, it is unlikely that Burns would have written in Scots. Without Burns, would poetry in Scots have continued to be written at the beginning of the 20th century? ${ }^{38}$

Ramsay does not attempt to replace the ancient political frontier by an insuperable linguistic barrier: his composite Scots aids comprehension and he does not refuse to write purely in English, even if these less frequent cases usually express a Scottish point of view, introducing references to Edinburgh, to Scotland, several Scots words and so on. ${ }^{39} \mathrm{His}$ composite language, fairly different from English, signifies to non-Scottish readers, especially in England, the Scottish difference. Given its qualities as an interesting cousin language of English and a worthy poetic language, Ramsay's poetic language also favours the respect of this difference. In other words, the language of Ramsay facilitates the comprehension and the respect of the whole set of differences between Scotland and England. ${ }^{40}$

Ramsay sought to "[...] save our Tongue/With numbers, Gloss, and Notes [...]". ${ }^{41}$ By making Scots poetry comprehensible and dignified he

alism, any possibility of a European-style vernacular-specific nationalist movement." (Anderson, Imagined Communities, p. 86)

37. The thematic index of a quite recent collection of Scottish Enlightenment texts signals more references to the language than any other subject. Morère, Écosse des Lumières, p. 425.

38. However, "no more than it is ethnic, the affirmation of identity (of present day Scotland) is not linguistic [...] It is above all social and cultural" (Civardi, L'Écosse, p. 220; our translation).

39. In the Advertisement to the first edition (1716) of "The Morning Interview", Ramsay underlines that it concerns an adventure in Edinburgh, and encourages local poetic production: "This City, as Narrow as it is, is the Scene of many Adventures, which may be proper Subject for both Poet and Philosopher." (W6, p. 23)

40. It may be that this predilection for Scots is part of the context of Enlightenment primitivism. The force of a modern "regional" language like Catalan may cause one to reject simplistic dichotomies between "nostalgic"/"reactionary" languages and "future-looking" ones.

41. "To his Grace John Duke of Roxburgh, The Address of Allan Ramsay, S[cots] P[oet]", [1722], W3, p. 162, 1. 29-30. 
partly succeeded. His work is thus an important part of the canon of Scottish poetry and typical of its and his frequently expressed concerns for the public role of the poet in debate within Scotland and with English neighbours, as well as for the politics of national identity. In particular, in the context of the worries of the Scottish Lowland elite as to the status and the propriety of their language and accent faced with (Southern) English (the dominant post-Union language of British power ${ }^{42}$ ), Ramsay takes a middle way between the more developed use of Scots (Robert Burns) and more markedly English writing (Walter Scott). He thus opened the debate over what are arguably the central questions of Scottish literature since 1707: language and identity.

\section{Bibliography}

Anderson Benedict, Imagined Communities: Reflections on the Origin and Spread of Nationalism [1983], London, Verso, 1990.

Givardi Christian, L'Écosse [1980], Paris, Seuil, 1990.

Corbett John, "The Spelling Practices of Allan Ramsay and Robert Burns", Language in Scotland: Corpus-Based Studies, Scottish Cultural Review of Language and Literature, no. 19, Wendy Anderson (ed.), Amsterdam, Rodopi, 2013, pp. 65-90.

CurTis Liz, Cause of Ireland: From the United Irishmen to Partition, Belfast, Beyond the Pale Publications, 1994.

Daiches David, "Scottish Literature from Allan Ramsay to Walter Scott", in D. Daiches (ed.), A Critical History of English Literature [1960], vol. 3, London, Secker, Warburg, 1969, pp. 808-55.

-, "Scottish Literature to 1700", in D. Daiches (ed.), A Critical History of English Literature, vol. 1, London, Secker, Warburg, 1961, pp. 505-34.

Devitt Amy J., Standardizing Written English: Diffusion in the Case of Scotland, 1520-1659, Cambridge, Cambridge UP, 1989.

Fullerton A., "Appendix Relative to His Life and Posthumous Reputation", in A. Fullerton (ed.), The Works of Allan Ramsay, vol. 3, London, 1848, pp. 209-411.

Grant William, "Introduction", in A. Warrack (ed.), Chambers Scots Dictionary [1911], Edinburgh, Chambers, 1974, pp. VI-XVII.

42. Murphy, "Allan Ramsay as Imitator of Horace”, pp. 123-9. Ramsay's homely, rural Horace contrasts with the urbane Horace of Alexander Pope's imitations, the latter being actively concerned with the politics of the capital city of empire. 
Inglis Alexander H., "Ramsay, Allan", in D. Daiches (ed.), The Penguin Companion to Literature: Britain and the Commonwealth, London, Penguin, 1971, pp. 436-7.

Jones George Fenwick, "Christis Kirk', 'Peblis to the Play', and the German Peasant-Brawl", Proceedings of the Modern Language Association, no. 68, 1953, pp. 1101-25.

KaY Billy, Scots: The Mither Tongue, Edinburgh, Mainstream, 1986.

Kinsley James, "The Rustic Inmates of the Hamlet", Review of English Literature, no. 1, 1960, pp. 13-25.

Kinghorn Alexander M. and Law Alexander, "Introduction", in A. M. Kinghorn and A. Law (eds), Poems by Allan Ramsay and Robert Fergusson, Edinburgh, Scottish Academic Press, 1974, pp. VII-XXXIV.

Letley Emma, From Galt to Douglas Brown: Nineteenth-Century Fiction and Scots Language, Edinburgh, Scottish Academic Press, 1988.

MaGlure J. Derrick, "Scottis, Inglis, Suddroun: Language Labels and Language Attitudes", Proceedings of the Third International Conference on Scottish Language and Literature, Roderick J. Lyall and Felicity Riddy (eds), Culross, Coupar Angus, 1981, pp. 52-69.

_, Why Scots Matters, Edinburgh, The Saltire Society, 1988.

MaGuirk Carol, "Augustan Influences on Allan Ramsay", Studies in Scottish Literature, vol. 16, 1981, pp. 97-109.

Moessner Lilo, "Besyde Latyn Our Langage Is Imperfite: The Contribution of Gavin Douglas to the Development of the Scots Lexicon", Études écossaises. Actes de l'atelier écossais de la conférence de l'E.S.S.E, Bordeaux 1993, Grenoble, Grenoble UP, 1994, pp. 5-17.

Morère Pierre (ed.), Écosse des Lumières. Le XVIII siècle autrement, Grenoble, Ellug, 1997.

Murphy Michael, "Ramsay as Imitator of Horace", Études écossaises, no. 2, 1993, pp. 123-9.

O Murahú Mairtín, The Irish Language, Dublin, Department of Foreign Affairs, 1985.

Pinkerton John, Ancient Scotish [sic] Poems, vol. 1, Edinburgh, 1786, pp. CXXXII-CXXXVI.

Ramsay Allan, The Works of Allan Ramsay, 6 vols, J. B. Martin, J. W. Oliver, A. M. Kinghorn, and A. Law (eds), Edinburgh, Blackwood, 1945-1979.

ReID David, The Party-Coloured Mind, Edinburgh, Scottish Academic Press, 1982.

Scoтt Walter, The Antiquary [1816], D. Hewitt (ed.), Harmondsworth, Penguin, 1998.

Smollett Tobias, Humphry Clinker [1771], A. Ross (ed.), Harmondsworth, Penguin, 1985. 